J. Clin. Chem. Clin. Biochem.

Vol. 16, 1978, pp. 245-248

\title{
A Simple and Sensitive Radiochemical Assay for Plasma Guanase
}

By C. A. van Bennekom, J. P. van Laarhoven, C. H. M. M. de Bruyn and T. L. Oei.

Department of Human Genetics, Faculty of Medicine, University of Nijmegen, Nijmegen, The Netherlands

(Received September 5/November 4, 1977)

Summary: A simple and sensitive radiochemical micro-assay has been developed for the determination of plasma guanase activity. The method is based upon the measurement of the conversion of ${ }^{14} \mathrm{C}$-labeled guanine to xanthine, catalysed by the enzyme guanase (guanine aminohydrolase; EC 3.5.4.3). Using this method, the catalytic activity in the plasma of adult healthy controls was $0.40 \pm 0.09 \mathrm{nmol} / \mathrm{h} \cdot \mathrm{mg}$ protein $(\overline{\mathrm{x}} \pm \mathrm{s})$. In children under 5 years of age higher levels of enzyme activity were demonstrated. In adult patients with liver disease plasma guanase activities were found to be 3 to 7 -fold increased as compared to the normal adult mean value.

\section{Einfache und empfindliche radiochemische Methode zur Bestimmung von Guanase im Plasma}

Zusammenfassung: Eine einfache und empfindliche radiochemische Mikromethode für die Bestimmung der katalytischen Aktivität von Guanase im Plasma wurde entwickelt. Sie basiert auf der durch Guanase (Guanin Aminohydrolase, EC 3.5.4.3) katalysierten Umsetzung von ${ }^{14} \mathrm{C}$-markiertem Guanin zu Xanthin. Im Plasma gesunder Erwachsener wurde mit dieser Methode eine katalytische Aktivität von $0,40 \pm 0,09 \mathrm{nmol} / \mathrm{h} \cdot \mathrm{mg}$ Protein $(\bar{x} \pm \mathrm{s})$ gefunden. Bei Kindern unter 5 Jahren wurden höhere Werte nachgewiesen. Bei erwachsenen Patienten mit Lebererkrankung betrug die katalytische Aktivität von Guanase im Plasma das 3-7fache der katalytischen Aktivität von gesunden Erwachsenen.

\section{Introduction}

Guanase (guanine-aminohydrolase; EC 3.5.4.3) is an enzyme of purine metabolism. It catalyses the deamination of guanine to xanthine:

$$
\text { Guanine }+\mathrm{H}_{2} \mathrm{O} \rightarrow \text { Xanthine }+\mathrm{NH}_{3}
$$

With respect to guanase activity normal mammalian tissues have been devided into three classes (1), those with high (liver, kidney, brain), those with intermediate (small and large intestine) and those with low activity (most other tissues and biologic fluids). Because of its relatively low level in normal human plasma, the appearance of significant guanase activity in this fluid has been introduced as an index for liver disease (2). In kidney disease both increased $(3,4)$ and decreased $(5)$ values have been observed.

Previous methods for the measurement of guanase activity have been based upon the determination of liberated ammonia (6), coupling to xanthine oxidase and the spectrophotometric measurement at $290 \mathrm{~nm}$ of the uric aric formed (7), upon the decrease in absorption at $245 \mathrm{~nm}$ as a result of guanine degradation (2) or upon the difference in native fluorescence of guanine and xanthine (8). Recently, a more sensitive radiochemical assay has been described, based on the measurement of the radioactive uric acid produced upon incubation with radioactive guanine and excess xanthine oxidase (3). In the present paper an equally sensitive and more simple radiochemical micro-assay for guanase in plasma is described. The enzyme activity is directly measured after electrophoretic separation of the labeled substrate and product.

\section{Materials and Methods}

\section{Preparation of the plasma}

Heparinized blood from healthy persons was obtained by venipuncture. After standing in an ice-bath for 10 minutes, the samples were centrifuged in a Christ UJl (15 min; $800 \mathrm{~g})$. The plasma was removed with a Pasteur pipette and used for analysis.

\section{Incubation with the plasma}

Plasma $(10 \mu \mathrm{l})$ was added to $10 \mu \mathrm{l} 0.25 \mathrm{~mol} / 1 \mathrm{Tris} / \mathrm{HCl}$ buffer pH 7.4, containing $1 \mathrm{nmol} 18-^{14} \mathrm{C}$ guanine (Radiochemical Centre, Amersham, England; spec. act. 2,07 GBq/mmol $\triangleq$ $56 \mathrm{mCi} / \mathrm{mmol}$ ). 
Pcr incubation mixture 700-1000 $\mu \mathrm{g}$ protein was incubated depending on the protein concentration of the plasma. Protein was estimated according to Lowry et al (9). All experiments were carried out in duplicate. After 60 minutes of incubation at $37^{\circ} \mathrm{C}$ the reaction mixtures were rapidly chilled and aliquots were taken for analysis.

\section{Analysis of reaction products}

An aliquot $(5 \mu \mathrm{l})$ of each incubation mixture was spotted on Whatmann 3 MM paper and submitted to high voltage electrophoresis (60 minutes; $70 \mathrm{~V} / \mathrm{cm}$ in acetic acid-pyridine-water buffer (Volumes, $9 \mathrm{ml}+1 \mathrm{ml}+90 \mathrm{ml} ; \mathrm{pH} \mathrm{3.6}$ ). Standard solutions with labeled guanine and xanthine were co-electrophoresed. After localization of the radioactive spots with the aid of a radiochromatogram scanner (Packard, model 7201) the spots were identified, cut out and placed in $10 \mathrm{ml}$ of scintillation fluid (toluene containing per liter: $5.5 \mathrm{~g}$ PPO, $0.1 \mathrm{~g}$ POPOP, and $50 \mathrm{ml}$ Triton X-100). The radioactivity of the spots was directly quantified in a liquid scintillation counter (Packard model 2450). Counting efficiency was about $90 \%$.

The action of plasma xanthine oxidase which converts xanthine to uric acid, will not interfere with the measurement, since uric acid has the same electrophoretic mobility as xanthine in this system, so that any uric acid formed is also measured as a product of the guanase activity.

\section{Results}

\section{Time curve}

The guanase-reaction was followed for 5 hours. Each 30 minutes a $5 \mu \mathrm{l}$ sample was taken for analysis.

Figure 1 shows that the reaction is linear up to 3 hours of incubation.

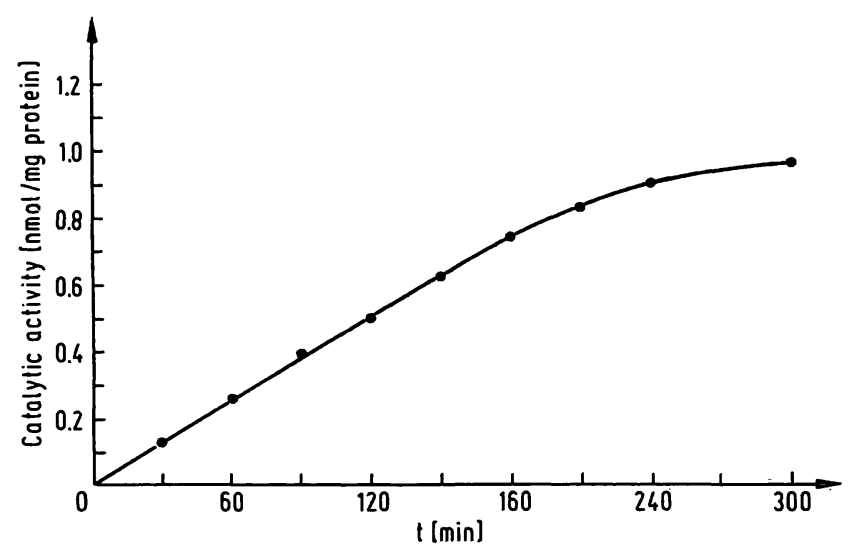

Fig. 1. Effect of incubation time on plasma guanase activity.

\section{Effect of protein concentration}

Incubations were carried out with different amounts of plasma protein (undiluted, $4 / 5,3 / 5,2 / 5$ and $1 / 5$ of the original amount of plasma protein, corresponding to approximately $1000 \mu \mathrm{g}$ to $200 \mu \mathrm{g}$ ). There was complete linearity between the amount of protein added and guanase activity (data not shown).

\section{Substrate affinity}

The effect of varying the substrate concentration on guanase activity is shown in figure $2 \mathrm{a}$.

The apparent $K_{\mathrm{m}}$ of guanine for guanase is $5.2 \mu \mathrm{mol} / 1$, as calculated from the Lineweaver-Burk plot (fig. $2 b$ ).

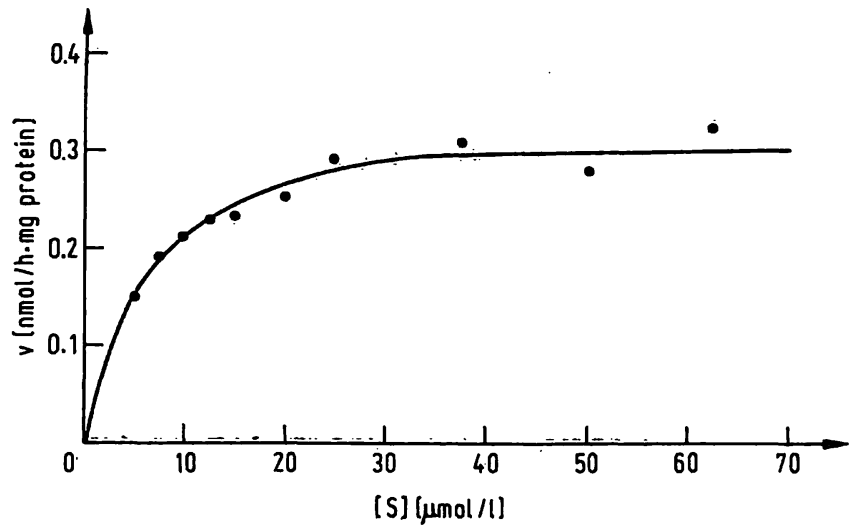

Fig. 2a. Effect of varying guanine concentrations on plasma guanase activity.

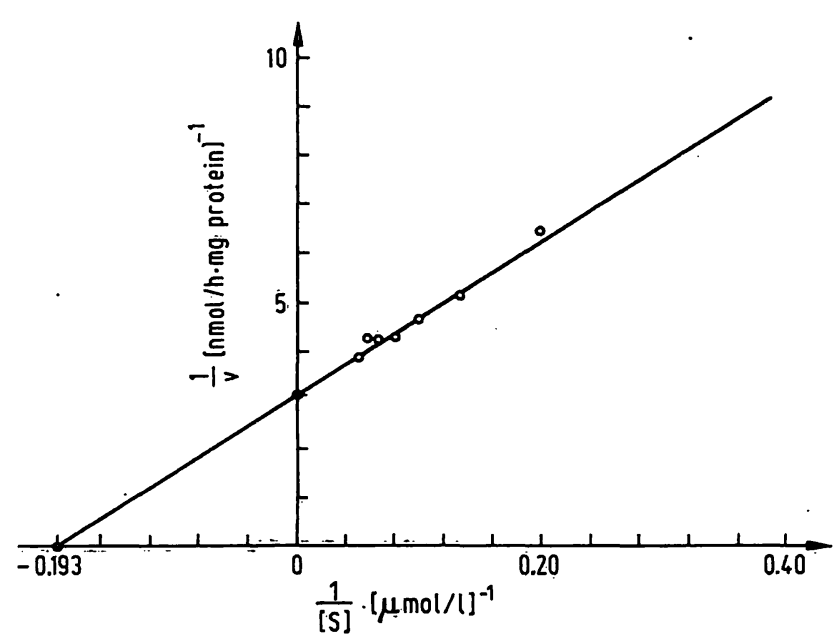

Fig. 2b. Lineweaver-Burk plot of the data shown in $2^{a}$.

\section{Product inhibition}

Varying amounts of xanthine up to $1.5 \mathrm{mmol} / 1$ were added to the reaction mixtures before starting the incubations. Even at the highest xanthine concentration there was no inhibition of the guanase reaction.

\section{Reproducibility}

Plasma was prepared from the blood of two control individuals and both samples were assayed for guanase activity. As can be seen in Table 1 the mean activity in one sample was $0.312 \mathrm{nmol} / \mathrm{h} \cdot \mathrm{mg}$ protein and in the other $0.416 \mathrm{nmol} / \mathrm{h} \cdot \mathrm{mg}$ protein. The standard deviations in both series of determinations were $0.022(6.8 \%)$ and $0.033(7.9 \%)$, respectively.

\section{Effect of storage}

Plasma samples were stored for $1,2,3,4$ and 7 days at $+5^{\circ} \mathrm{C}$ and $-21^{\circ} \mathrm{C}$. After 7 days storage at both temperatures $90 \%$ of the original activity was still present.

\section{Guanase activity in controls}

A group of 49 healthy adults (24 females and 25 males) was tested for guanase activity in plasma. 
Tab. 1. Reproducibility of the plasma guanase assay: samples from two controls were each tested ten times. Enzyme activities are in nmoles of product formed per $\mathrm{mg}$ protein per hour.

\begin{tabular}{lll}
\hline assay no. & $\begin{array}{l}\text { sample I } \\
\text { [nmol/h } / \mathrm{hg} \text { protein] }\end{array}$ & sample II \\
\hline 1 & 0.310 & 0.467 \\
2 & 0.337 & 0.378 \\
3 & 0.340 & 0.439 \\
4 & 0.308 & 0.386 \\
5 & 0.292 & 0.412 \\
6 & 0.312 & 0.389 \\
7 & 0.311 & 0.449 \\
8 & 0.302 & 0.386 \\
9 & 0.273 & 0.402 \\
10 & 0.339 & 0.456 \\
$\bar{x} \pm s$ & $0.312 \pm 0.022$ & $0.416 \pm 0.033$ \\
\hline
\end{tabular}

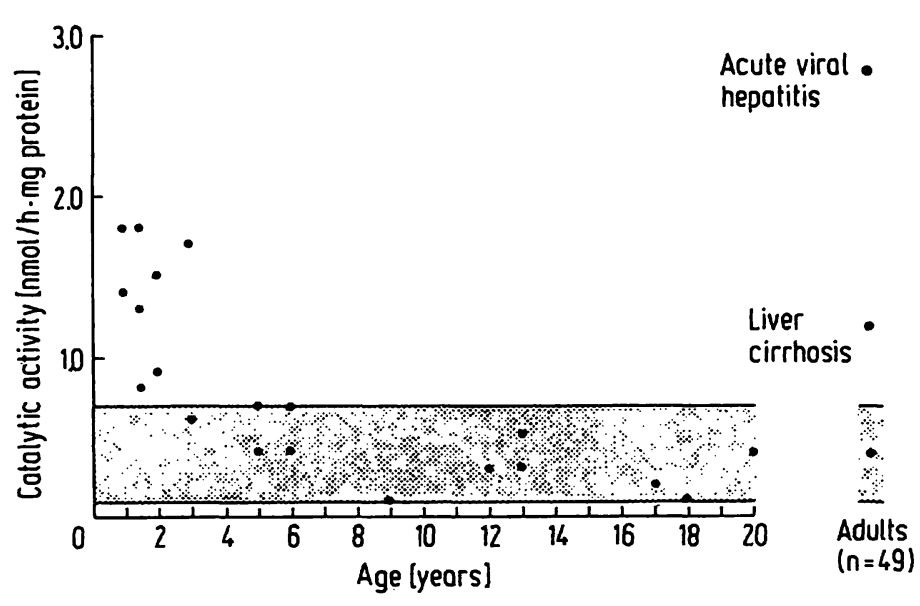

Fig. 3. Plasma guanase activity in individuals with different ages and in two adult patients with liver disease (liver cirrhosis and acute viral hepatitis). The hatched horizontal bar indicates the normal adult range, i.e. $\bar{x} \pm 3 s$.

The mean value of xanthine formed in females was $0.407 \pm 0.085(\bar{x} \pm s)$ and in males $0.391 \pm 0.102(\bar{x} \pm s)$ $\mathrm{nmol} / \mathrm{h} \cdot \mathrm{mg}$ protein.

\section{Determination of guanase activity in adult patients with liver disease}

Plasma from patients with liver disease associated with elevated bilirubin levels was assayed. As can be seen in figure 3 the 2 patients displayed markedly increased plasma guanase.

\section{Effect of age on plasima guanase activity}

In individuals between 5 and 18 years the guanase activity range $(\overline{\mathrm{x}} \pm 3 \mathrm{~s})$ was found to be comparable with the adult range (fig. 3). In children under 5 years of age the enzyme activity was significantly higher, even as high as a 4-5 fold increase over the adult mean value.

\section{Discussion}

The radiochemical micro-assay for plasma guanase described in this paper differs from the previously reported radio-isotopic methods $(3,5)$ in that it directly measures the conversion of guanine to xanthine; no second step reaction is needed. A very reproducible separation between guanine and xanthine can be obtained with high voltage electrophoresis under the present conditions. Guanine migrates $5 \mathrm{~cm}$ in the cathodal direction and xanthine remains on the application spot. Not only the formation of the reaction product can be followed, but also the disappearance of the substrate. The lowest detectable amount of enzyme catalytic activity is $1 \mathrm{pmol} / \mathrm{h} \cdot \mathrm{mg}$ protein.

Apart from the fact that it is over a thousand fold more sensitive than non-isotopic methods, the radiochemical assay has the advantage of general applicability. In contrast to the spectrophotometric and fluorometric assays it is not influenced by the turbidity or colour of the sample and therefore it is perfectly suited for measurements with any type of biological fluid or cell lysate.

In the past few years evidence has been accumulating that the plasma guanase activity is a sensitive index for liver and kidney disease. The occurrence of a pronounced rise in patients with acute liver disease (hemolytic jaundice, infectious hepatitis, liver cirrhosis) is now well documented $(2,3)$; see also our fig. 3$)$. In more than $75 \%$ of patients with endemic nephropathy an increase in plasma guanase activity was observed (4). This phenomenon has been attributed to epithelial cell destruction and cytolysis in the renal tubuli (4). On the other hand decreased levels of plasma guanase have been reported in patients with uraemia and in rabbits with induced kidney disease (5). It has been suggested that in the normal subject the kidney is the main source of the circulating guanase and that this production might be decreased in a diseased kidney (5). It seems beyond doubt that the findings cited above point to different forms of renal disease.

It should be noted that in children under 4-5 years the plasma guanase activity is clearly higher than that in older children and adults, e.g. the guanase activity in the adult patient with liver cirrhosis is in the same range as the control values for healthy children under 5 years (fig. 4). For a correct interpretation of the data from young individuals the age dependency of plasma guanase activity should be taken into account.

From the foregoing it can be concluded that determination of plasma guanase activity might become increasingly important in diseases associated with destructive cellular changes, such as in viral and toxic hepatitis $(2,8)$, liver cancer (10), leukemia (11) and renal impairment $(4,5)$.

\section{Acknowledgements}

The authors thank Dr. H. J. M. van Tongeren (Dept. Internal Medicine, University Hospital, Nijmegen) for the opportunity to study plasma samples from the patients with liver disease and Prof. Dr. S. J. Geerts (Head of the Department of Human Genetics, University of Nijmegen) for critically reading the manuscript. 


\section{References}

1. Levine, R., Hall, T. C. \& Harris, C. A. (1963), Cancer 16, 269-272.

2. Knights, E. M., Whitehouse, J. L., Hue, A. C. \& Santos, C. L. (1965), J. Lab. Clin. Med. 65, 355-360.

3. Al-Khalidi, U. A. S., Aftimos, S., Musharrafieh, S. \& Khuri, N. N. (1970), Clin. Chim. Acta 29, 381-384.

4. K. Pradanov \& Astrug, A. (1971), Clin. Chim. Acta 35, 445-448.

5. Kebejian, G. Y. \& Al-Khalidi, U. A. S. (1973), Europ. J. Clin. Invest. 3, 41-43.

6. Nyssen, M. \& Dorcke, J. (1968), Clin. Chim. Acta 22, 363= 372.

7. Roush, A. \& Norris, E. R. (1950), Arch. Biochem. Biophys. 29, 124-129.

8. Bieber, A. L. (1974), Analyt. Biochem. 59, 354-359.

9. Lowry, O. H., Rosebrough, N. J., Farr, A. L. \& Randall, R. J. (1951), J. Biol. Chem. 193, 265-275.

10. Bel, A., Dietsch, R., Alary, R., Savoye, B., Levrat, R., Nesmoz, J. \& Nyssen, M. (1970), Presse Méd. 78, 495-499.

11. Serban, M., Cucu, C., Mihailescu, E. \& Micu, D. (1974), Rev. Roum. Méd. Int. 11, 319-324.

Dí. C. H. M. M. de Bruyn Dept. Human Genetics Faculty of Medicine University of Nijmegen Nijmegen - The Netherlands. 